\title{
Association of the Fusarium Wilt Race 3 Resistance Gene, I-3, on Chromosome 7 with Increased Susceptibility to Bacterial Spot Race T4 in Tomato
}

\author{
Samuel F. Hutton ${ }^{1}$, John W. Scott, and Gary E. Vallad \\ Gulf Coast Research and Education Center, Institute of Food and Agricultural Sciences, University of \\ Florida, 14625 CR 672, Wimauma, FL 33598-6101
}

\begin{abstract}
AdDitional INDEX words. broad-spectrum resistance, linkage drag, pleiotropy, quantitative trait loci, Xanthomonas
Abstract. Bacterial spot of tomato (Solanum lycopersicum), caused by several Xanthomonas species, is one of the most important diseases of the crop in humid production regions of the world. Conventional breeding approaches for resistance to bacterial spot previously identified race-specific resistances, but current efforts also seek to use quantitative trait loci (QTLs) effecting broad-spectrum resistance. Resistance QTLs and candidate QTLs have been reported on several chromosomes, including a major QTL on chromosome 11. Fusarium wilt (Fusarium oxysporum f. sp. lycopersici) race 3 resistance gene, $I-3$, is associated with smaller fruit size and has been implicated in other associations with negative characteristics. We evaluated four $F_{2}$ populations involving the bacterial spot-tolerant breeding lines Fla. 8517, Fla. 8233, and Fla. 8326 across two field seasons to validate and quantify previously identified loci and to test for an effect of I-3 on bacterial spot sensitivity. The chromosome 11 QTL and the I-3 locus were each consistently positively and negatively associated with resistance, respectively, and together explained from $44 \%$ to $47 \%$ of the variation in each population. The chromosome 11 QTL displayed a dominant to incompletely dominant effect, reducing infection by $14 \%$ to $25 \%$. This QTL is distinct from the $X$. perforans race T3 hypersensitivity loci, $R x-4$ and $X v 3$. The $I-3$ locus contributed to as much as a $20 \%$ increase in infection in $I-3 / I-3$ plants vs. $i-3 / i-3$ plants, and heterozygosity for $I-3$ generally resulted in an intermediate susceptible response. Significant effects for QTLs on chromosomes 3,5 , and 12 were also observed, but these effects were not consistent in all populations or seasons in which they were segregating. Implications of these findings toward breeding strategies are discussed.
\end{abstract}

Tomato is one of the most economically important vegetable crops in the world. In 2012, production reached nearly 162 million tonnes worldwide, more than a $70 \%$ increase in production over 1996 levels (Food and Agriculture Organization of the United Nations, 2014). The United States is among the leading producers of tomatoes in both processing and fresh markets. Approximately 1.38 million tonnes of fresh-market tomatoes were produced in the United States in 2012 and valued at \$864 million [U.S. Department of Agriculture (USDA), 2012]. Fresh-market tomato production is the number one vegetable industry in Florida, where a subtropical climate allows for winter production while also creating a favorable environment for numerous diseases in the crop.

Fusarium wilt, caused by the soilborne fungus Fusarium oxysporum f. sp. lycopersici, has been a major disease of tomato in Florida and in other warm production regions worldwide. The fungus colonizes the vascular tissue of plants after infecting the roots by direct penetration or through wounds. Host resistance has proven to be an effective control strategy in commercial cultivars and relies primarily on three single dominant genes that have been discovered and introgressed from Solanum pimpinellifolium (I and I-2) or from Solanum pennellii (I-3) and which confer resistance to three races of the pathogen. Bohn and Tucker (1939) identified a single gene conferring resistance to race 1 , which they termed $I$ for "immunity." Race 2 resistance was discovered by Alexander (1959) and subsequently characterized by Stall and Walter (1965), who named the gene $I-2$. Both $I$ and $I-2$ are located on chromosome 11 , and $I-2$ has

Received for publication 10 Jan. 2014. Accepted for publication 11 Feb. 2014. ${ }^{1}$ Corresponding author. E-mail: sfhutton@ufl.edu. been positionally cloned (Simons et al., 1998). Resistance to race 3 was reported by McGrath et al. (1987) and by Scott and Jones (1989b), and I-3 has been fine-mapped on chromosome 7 (Lim et al., 2008). Although cultivars containing $I-3$ are quite common and have been commercially available since the early 1990s, there have been some difficulties in developing commercially acceptable race 3-resistant hybrids. Some of the earliest $I-3$ parents had a greater susceptibility to blossom-end rot (Scott and Jones, 2004; J.W. Scott, unpublished data). Scott (1999) also showed that homozygosity for $I-3$ resulted in reduced fruit size compared with heterozygosity. Moreover, the consensus among breeders is that $I-3$ is associated with weaker vines and may also be associated with a greater susceptibility to bacterial spot (J.W. Scott, unpublished data).

Bacterial spot is also a major disease of tomato in Florida and in many regions of the world where the crop is grown in humid environments. The disease is caused by several species of Xanthomonas, including $X$. euvesicatoria (race T1), $X$. vesicatoria (race T2), $X$. perforans (races T3 and T4), and $X$. gardneri (Jones et al., 2000, 2005). There is no good control measure commercially available for bacterial spot. Copper compounds have been and are widely used but are largely ineffective as a result of resistance in bacterial populations (Horvath et al., 2012; Marco and Stall, 1983; Quezado-Duval et al., 2003). Chemicals that induce systemic acquired resistance and bacteriophages provide alternative control strategies (Byrne et al., 2005; Louws et al., 2001; Obradovic et al., 2005), but these are not widely used in commercial production.

Bacterial spot symptoms occur on leaves, stems, and fruit of tomato. Infected fruit are unmarketable, whereas leaf and stem infections cause defoliation, which may result in reduced yield 
and quality as a result of cracking, sunscald, or black shoulder (Scott and Jones, 1986). Yield losses resulting from bacterial spot can be severe. Pohronezny and Volin (1983) compared yields of non-inoculated plots with those that were inoculated at one of two different times. Compared with the non-inoculated control, reductions in total yield ranged from $22 \%$ in the lateinoculated plots to $52 \%$ in the early-inoculated plots; the authors also showed a $42 \%$ to $66 \%$ reduction in yields of USDA largesized fruit in the early-inoculated plots. Horvath et al. (2012) reported a very high level of resistance to bacterial spot was achieved in transgenic tomatoes expressing the $B s 2$ resistance gene from pepper (Capsicum annum). In repeated trials, Bs2 transgenic lines and hybrids showed a 1.5 -fold or greater yield increase over non-transgenic isogenic lines and hybrids, and yield increases were consistently 2 -fold or greater under periods of greater disease pressure (Horvath et al., 2012, 2014).

Much conventional breeding research has been directed toward identification of sources of host resistance to bacterial spot, incorporation of this resistance into cultivated germplasm, and elucidation of the genetic control of resistance. For the most part, these efforts have focused on single pathogen races and have led to the identification and mapping of several single genes regulating resistance. Yang et al. (2005) confirmed a major role for $R x-3$ from Hawaii 7998 (H7998) in field resistance to $X$. euvesicatoria race T1. Xv3 from Hawaii 7981 (H7981) and $R x-4$ from the $S$. pimpinellifolium accession PI128216 condition hypersensitivity to $X$. perforans race T3 (Robbins et al., 2009; Scott et al., 1996; Wang et al., 2011). RXopJ4 from $S$. penellii accession LA716 controls hypersensitivity to $X$. perforans races T3 and T4 (Sharlach et al., 2013). These loci, however, provide only partial resistance, and additional QTLs are often necessary for field resistance (Scott et al., 2001; Scott and Jones, 1989a; Somodi et al., 1996; Wang et al., 1994).

In addition to the use of such single, race-specific resistance genes, there is ongoing research to identify and use QTLs conferring a more broad-spectrum, race-nonspecific resistance (Hutton et al., 2010a, 2012; Scott et al., 2003). Hutton et al. (2010b) identified QTLs significantly associated with resistance on chromosomes 3,11 , and 12, as well as candidate QTLs on chromosomes 1, 2, 5, 9, and 10. Of these, the chromosome 11 QTL had the largest effect and was mapped near the location of the race T3 hypersensitivity loci, $X v 3$ and $R x-4$ (Robbins et al., 2009; Wang et al., 2011). The objectives of this research were primarily to determine what effect $I-3$ has on bacterial spot sensitivity; secondary objectives were to validate and quantify the effect of the QTLs previously identified for bacterial spot resistance on chromosome 11 and at other loci and to determine the location of the chromosome 11 QTL relative to the race $\mathrm{T} 3$ hypersensitivity locus.

\section{Materials and Methods}

Plant materials. Three bacterial spot-tolerant breeding lines developed at the University of Florida, Fla. 8233, Fla. 8517, and Fla. 8326, were each crossed with Fla. 7946, and Fla. 8233 was also crossed with Fla. 8111B. Both Fla. 7946 and Fla. 8111B are highly susceptible to bacterial spot, and Fla. 7946 has resistance to fusarium wilt race 3 (F. oxysporum. f. sp. lycopersici) conferred by the $I-3$ gene on chromosome 7 (Scott, 2004). The resulting $F_{1}$ s from these crosses were allowed to self-pollinate, and $\mathrm{F}_{2}$ populations were evaluated for bacterial spot in the field at Balm, FL, in Fall 2008 and/or Fall 2009.
For all experiments, seed were sown directly into peat-lite soilless media (Speedling, Sun City, FL) in 128-well flats $\left(38 \mathrm{~cm}^{3}\right.$ cell size; Speedling). Transplants were grown in a greenhouse and planted to the field $\approx 5$ weeks after sowing. Plants were transplanted to field beds that were $20 \mathrm{~cm}$ high and $81 \mathrm{~cm}$ wide and had been fumigated with a 50:50 mixture of methyl bromide and chloropicrin (55 kg per treated hectare) and covered with white plastic mulch. Plants were spaced $46 \mathrm{~cm}$ apart in rows with $152 \mathrm{~cm}$ between rows. Plants were staked and tied and were irrigated by drip tape beneath the plastic mulch of each bed. A recommended fertilizer program was followed, and plants were sprayed with pesticides (excluding copper and other bactericides) as needed throughout the season (Olson et al., 2011).

EXPERIMENTAL DESIGN. In Fall 2008, parents and $\mathrm{F}_{2}$ populations from the crosses (Fla. $8233 \times$ Fla. 8111 B), (Fla. $8517 \times$ Fla. 7946), and (Fla. $8326 \times$ Fla. 7946) were sown with their respective parents on 23 July. $\mathrm{F}_{1} \mathrm{~s}$ were also sown at this time for the Fla. 8233 and Fla. 8517 populations. Parents, $F_{1} s$ and $F_{2} s$, were planted in three separate experiments, each corresponding to one of the three crosses. Transplants were planted to the field on 26 Aug. Parents and $F_{1} s$ were planted in a randomized complete block design with three blocks and eight-plant plots (except for the Fla. 8517 population, in which plots were 12- to 13-plant plots). Each $\mathrm{F}_{2}$ population consisted of 270 plants planted in nine 30-plant plots that were distributed evenly and placed randomly across the three blocks. Experiments were inoculated with $X$. perforans race T4 in the evening on 24 Sept. and again before sunrise on 10 Oct. (because weather conditions were cool and dry at the first inoculation and thus unfavorable for disease development). Plants were rated individually for bacterial spot disease severity between 29 and 31 Oct. Tissue was collected and DNA was extracted from each $\mathrm{F}_{2}$ plant. On 3 Nov., two cuttings were taken from each $\mathrm{F}_{2}$ plant in the (Fla. $8517 \times$ Fla. 7946) $F_{2}$ population as well as from 13 or more plants of each of the two parents and the $F_{1}$. Cuttings were rooted in a 1:1 perlite:vermiculite media under mist for 2 weeks and then transplanted to small pots. One cutting from each $\mathrm{F}_{2}$ plant and the cuttings from the parents and the $\mathrm{F}_{1}$ were infiltrated with $X$. perforans race T3 on 9 Dec. for evaluation of hypersensitivity to race T3 as described below.

In Fall 2009 , seed were sown on 22 July to generate $\approx 850 \mathrm{~F}_{2}$ plants from the Fla. $8517 \times$ Fla. 7946 cross and $\approx 750 \mathrm{~F}_{2}$ plants from the Fla. $8233 \times$ Fla. 7946 cross along with the respective parents of these populations. Tissue was collected and DNA extracted from each $\mathrm{F}_{2}$ plant, and seedlings were genotyped for the chromosome 11 QTL using the marker UF_C2_At4g10050 and for the $I-3$ locus using the marker UF_I-3 CAPS (Table 1). Half of the plants heterozygous for the chromosome 11 marker and half of the plants heterozygous at the $I-3$ locus were removed from the population to balance the representation from each allelic category. Parents and the $\mathrm{F}_{2} \mathrm{~s}$ were planted into two separate experiments according to the two crosses. Transplants were planted to the field on 11 Sept. For each population, a randomized complete block design was used with three blocks and 12-plant plots; each block included one plot for each parent and nine plots for the $\mathrm{F}_{2}$. Experiments were inoculated with $X$. perforans race T4 on $28 \mathrm{Sept}$. Plants were rated individually for bacterial spot disease severity on 3 Nov. In the field, tissue was collected from individual plants for DNA extraction and marker analysis.

DNA EXTRACTION AND MARKER ANALYSES. For all experiments, DNA was extracted using a modified cetyltrimethylammonium 


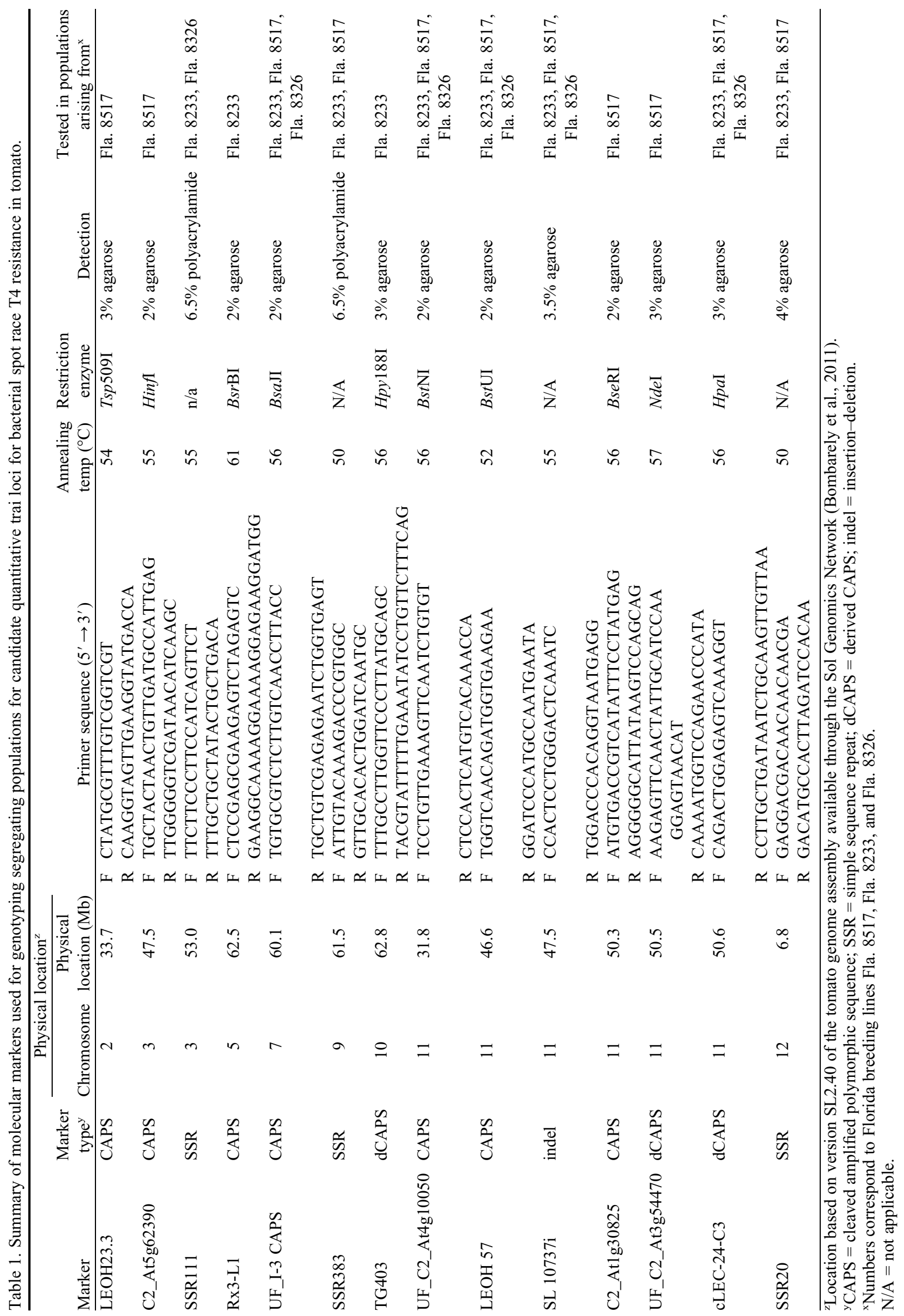


bromide procedure as described by Fulton et al. (1995). Molecular markers, their chromosomal locations, and parameters are described in Table 1. Markers were selected based on candidate QTL identified previously (Hutton et al., 2010b). For each population and within each year, a stepwise analysis of variance was performed using the MIXED procedure of SAS (Version 9.1; SAS Institute, Cary, NC) to determine which loci were significantly associated with resistance and to test for interactions; the GLM procedure of SAS was used to perform Duncan's means separation to quantify the effect of each locus.

INOCULUM PREPARATION, PLANT INOCULATIONS, AND DISEASE EVALUATIONS. $X$. perforans race T3 inoculum was produced by growing the bacteria on Difco nutrient agar (Becton Dickinson and Co., Sparks, MD) for 24 to $36 \mathrm{~h}$ at $28^{\circ} \mathrm{C}$. Bacterial cells were removed from the agar plates and suspended in $10 \mathrm{~mm}$ $\mathrm{MgSO}_{4} \cdot 7 \mathrm{H}_{2} \mathrm{O}$, and the suspensions were standardized to $\mathrm{A}_{600}=$ 0.30 [a concentration of $\approx 2$ to $5 \times 10^{8}$ colony-forming units $(\mathrm{cfu}) / \mathrm{mL}$. Leaves of cuttings were infiltrated with the bacterial suspension as described by Hibberd et al. (1987), and hypersensitivity was evaluated as described by Scott et al. (1996) with some modifications. Briefly, infiltrated plants were maintained in a greenhouse that ranged from $13{ }^{\circ} \mathrm{C}$ at night to $24{ }^{\circ} \mathrm{C}$ during the day. Assessments for hypersensitive reactions were carried out at 12- to 24-h intervals between 24 and $72 \mathrm{~h}$ after infiltration. Infiltrated areas exhibiting confluent necrosis within $36 \mathrm{~h}$ were scored as hypersensitive.

Field trials were inoculated with $X$. perforans race T4 for two reasons; first because this race is both predominant and endemic in Florida; and second because there is no race-specific resistance in the germplasm used for this study, and race T4 is therefore suitable for testing non-race-specific resistance. Race $\mathrm{T} 4$ inoculum was produced as described previously for race T3, and the bacterial suspensions were adjusted to a concentration of $\approx 2$ to $5 \times 10^{6} \mathrm{cfu} / \mathrm{mL}$. Inoculum was applied along with an organosilicone surfactant $[0.025 \%$ v/v (Silwet L77; Setre Chemical Co., Memphis, TN)] by misting the foliage with a backpack sprayer. Plants in the field were rated on each side of the staked row for disease severity using the Horsfall-Barratt (HB) scale (Horsfall and Barratt, 1945), where $1=0 \%, 2=0 \%$ to $3 \%, 3=3 \%$ to $6 \%, 4=6 \%$ to $12 \%, 5=12 \%$ to $25 \%, 6=25 \%$ to $50 \%, 7=50 \%$ to $75 \%, 8=75 \%$ to $87 \%, 9=87 \%$ to $94 \%, 10=$ $94 \%$ to $97 \%, 11=97 \%$ to $100 \%$, and $12=100 \%$ diseased tissue; where there was a discrepancy between the ratings of the two sides of a plant, an average rating was recorded. For presentation purposes, midpoints of the ranges above were used to convert $\mathrm{HB}$ ratings to percent disease for individual plants.

\section{Results}

Bacterial spot disease pressure in the fall seasons of 2008 and 2009 resulted in severe infections on susceptible parents, from which resistant parents were clearly distinguished in all populations (Table 2). Mean disease severities of $F_{2}$ populations were intermediate to the parents, and individual plant ratings of $\mathrm{F}_{2}$ populations generally fell within the range of the two parents.

Stepwise analysis of variance identified two major loci affecting bacterial spot disease severity, one on chromosome 11 and one at the $I-3$ locus on chromosome 7 (Table 3). These loci together explained between $44 \%$ and $47 \%$ of the variation in each population. The chromosome 11 QTL was significant in every population across both years and was always represented in the model by the marker C2_At4g10050, which consistently explained more variation than nearby chromosome 11 markers located more distal on the chromosome. The effect of this QTL varied between dominance and incomplete dominance. Homozygosity for this QTL lowered disease from 14\% in both the Fla. 8233 and Fla. 8326 populations in 2008 to $25 \%$ in the 2009 Fla. 8517 population. Heterozygosity for the chromosome 11 QTL had a similar effect to homozygosity in all three populations tested in 2008 , reducing disease by $10 \%$ to $21 \%$, yet in both populations tested in 2009, the heterozygous effect of this QTL, although quite strong, was slightly less than the homozygous effect.

Resistance to fusarium wilt race 3 was associated with greater susceptibility to bacterial spot in all populations segregating for $I-3$. The most pronounced effect was observed in the Fla. 8326 population, where homozygosity for $I-3$ resulted in $20 \%$ greater diseased tissue than the absence of this allele (Table 3 ). In the 2008 Fla. 8517 and the 2009 Fla. 8233 populations,

Table 2. Bacterial spot race $\mathrm{T} 4$ disease severity for tomato parents and their derived $\mathrm{F}_{2}$ generations.

\begin{tabular}{|c|c|c|c|c|c|c|c|}
\hline \multicolumn{8}{|c|}{ Season } \\
\hline \multicolumn{4}{|c|}{ Fall 2008} & \multicolumn{4}{|c|}{ Fall 2009} \\
\hline & \multirow[b]{2}{*}{ Plant no. } & \multicolumn{2}{|c|}{ Disease severity index $^{z}$} & \multirow[b]{2}{*}{ Line } & \multirow[b]{2}{*}{ Plant no. } & \multicolumn{2}{|c|}{ Disease severity index } \\
\hline Line & & Mean & Range & & & Mean & Range \\
\hline Fla. $8111 \mathrm{~B}$ & 23 & $6.4 \mathrm{a}$ & $6-7$ & Fla. 7946 & 34 & $6.9 \mathrm{a}$ & $6-7$ \\
\hline$\left(\right.$ Fla. $8233 \times$ Fla. 8111 B) $\mathrm{F}_{2}$ & 283 & $4.5 \mathrm{~b}$ & $2-7$ & $($ Fla. $8233 \times$ Fla. 7946$) \mathrm{F}_{2}$ & 312 & $5.4 \mathrm{~b}$ & $3.5-7$ \\
\hline (Fla. $8233 \times$ Fla. 8111 B) $F_{1}$ & 19 & $4.3 \mathrm{~b}$ & $3-5$ & & & & \\
\hline Fla. 7946 & 39 & $6.3 \mathrm{a}$ & $6-6.5$ & Fla. 7946 & 36 & $7.0 \mathrm{a}$ & $6.5-7$ \\
\hline$($ Fla. $8517 \times$ Fla. 7946$) \mathrm{F}_{2}$ & 256 & $3.5 \mathrm{~b}$ & $2-7$ & (Fla. $8517 \times$ Fla. 7946) $\mathrm{F}_{2}$ & 297 & $5.5 \mathrm{~b}$ & $3-7$ \\
\hline$\left(\right.$ Fla. $8517 \times$ Fla. 7946) $\mathrm{F}_{1}$ & 34 & $3.4 \mathrm{~b}$ & $3-4$ & & & & \\
\hline Fla. 8326 & 24 & $4.0 \mathrm{c}$ & $3-5$ & & & & \\
\hline Fla. 7946 & 23 & $6.7 \mathrm{a}$ & $6-7$ & & & & \\
\hline (Fla. $8326 \times$ Fla. 7946$) \mathrm{F}_{2}$ & 241 & $5.7 \mathrm{~b}$ & $3-7$ & & & & \\
\hline
\end{tabular}

${ }^{\mathrm{z}}$ Disease severity index rated on the Horsfall-Barratt (Horsfall and Barratt, 1945) scale, where higher numbers indicate more disease. yDifferent superscript letters represent statistically significant differences among lines in a population at $P<0.05$ based on Duncan's multiple range test. 
Table 3. Effect of two loci on bacterial spot race T4 foliar disease severity in tomato across four populations and two seasons.

\begin{tabular}{|c|c|c|c|c|c|c|c|c|c|}
\hline \multirow[b]{2}{*}{ Population } & \multirow[b]{2}{*}{ Season } & \multirow[b]{2}{*}{ Genotype $^{z}$} & \multicolumn{3}{|c|}{ I-3 (UF_I-3 CAPS) } & \multicolumn{3}{|c|}{ Chromosome 11 QTL (UF_C2_At4g10050) } & \multirow[b]{2}{*}{$R^{2}$} \\
\hline & & & Plant no. & Mean DSI ${ }^{\mathrm{y}}$ & Dis. $(\%)^{\mathrm{x}}$ & Plant no. & Mean DSI & Dis. (\%) & \\
\hline \multirow[t]{2}{*}{ (Fla. $8233 \times$ Fla. 8111 B) } & Fall 2008 & $+/+$ & & & & 70 & $4.1 \mathrm{~b}$ & 11 & \\
\hline & & $+/-$ & & & & 100 & $4.2 \mathrm{~b}$ & 12 & 44 \\
\hline \multirow[t]{3}{*}{ (Fla. $8233 \times$ Fla. 7946$)$} & Fall 2009 & $+/+$ & 103 & $5.7 \mathrm{a}$ & 32 & 98 & $4.9 \mathrm{c}$ & 19 & \\
\hline & & $+/-$ & 103 & $5.4 \mathrm{~b}$ & 28 & 104 & $5.3 \mathrm{~b}$ & 25 & 45 \\
\hline & & $-1-$ & 103 & $5.2 \mathrm{c}$ & 25 & 98 & $6.1 \mathrm{a}$ & 41 & \\
\hline & & $+/-$ & 111 & $3.3 \mathrm{~b}$ & 9 & 137 & $3.1 \mathrm{~b}$ & 6 & 47 \\
\hline & & $-1-$ & 62 & $3.0 \mathrm{c}$ & 7 & 46 & $5.3 \mathrm{a}$ & 27 & \\
\hline (Fla. $8517 \times$ Fla. 7946$)$ & \multirow[t]{3}{*}{ Fall 2009} & $+/+$ & 99 & $5.5 \mathrm{a}$ & 30 & 97 & $4.9 \mathrm{c}$ & 20 & \\
\hline & & $+/-$ & 105 & $5.7 \mathrm{a}$ & 33 & 97 & $5.3 \mathrm{~b}$ & 26 & 46 \\
\hline & & $-1-$ & 92 & $5.4 \mathrm{~b}$ & 28 & 98 & $6.3 \mathrm{a}$ & 45 & \\
\hline (Fla. $8326 \times$ Fla. 7946$)$ & Fall 2008 & $+/+$ & 58 & $6.2 \mathrm{a}$ & 44 & 46 & $5.4 \mathrm{~b}$ & 28 & \\
\hline
\end{tabular}

$\mathrm{z}_{+} /+=$homozygous for fusarium wilt race 3 resistance or for the resistant allele at the chromosome 11 quantitative trait loci; $+/-=$ heterozygous; $-/-=$ homozygous-susceptible.

${ }^{y}$ Disease severity index rated on the Horsfall-Barratt (Horsfall and Barratt, 1945) scale, where higher numbers indicate more disease. Different superscript letters represent statistically significant differences among genotypes in a population and year at $P<0.05$ based on Duncan's multiple range test.

xPercentage diseased tissue as converted from Horsfall-Barratt ratings.

homozygosity resulted in $9 \%$ and $7 \%$ greater disease, respectively. The smallest effect was observed in 2009 in the Fla. 8517 population, where homozygosity for $I-3$ resulted in only a $2 \%$ increase in disease over $i-3 / i-3$ genotypes. In this population, heterozygosity for $I-3$ resulted in greater disease than homozygosity; in all other populations, however, I-3 had an additive effect, and heterozygosity at $I-3$ resulted in intermediate disease severity between homozygous-resistant and homozygoussusceptible. Within each of these populations, an intermediate phenotype was observed for plants homozygous for both I-3 and the chromosome 11 QTL (data not shown); average disease severities of these plants were approximately equal to the mean $\mathrm{F}_{2}$ disease severity indices presented in Table 2 .

QTL were also detected in some populations on chromosomes 3, 5, and 12, but effects were not consistent across both seasons (data not shown). In 2008, homozygosity for a QTL on chromosome 3 provided a $2 \%$ reduction in disease in the Fla. 8517 population and a 5\% reduction in the Fla. 8326 population; this QTL was not significant in the Fla. 8517 population in 2009 nor in the Fla. 8233 populations. Homozygosity for a QTL on chromosome 5 significantly lowered disease by $3 \%$ in the 2008 Fla. 8233 population, but no effect was observed in 2009 . Likewise, a QTL on chromosome 12 lowered disease by $4 \%$ in the Fla. 8233 population in 2008 and by $8 \%$ in the 2009 Fla. 8517 population, but the same locus had no significant effect in the 2009 Fla. 8233 population or the 2008 Fla. 8517 population. No effect was observed for candidate QTL on chromosomes 2, 9 , or 10 , and no interactions were detected among any of the loci that significantly affected disease.

Genes controlling $X$. perforans race $\mathrm{T} 3$ hypersensitivity are located in the same region as the chromosome 11 QTL confirmed in this study (Robbins et al., 2009; Wang et al., 2011). To determine the relationship between the two traits, race T3 hypersensitivity was measured on individuals of the Fall 2008 Fla. 8517 population. Tests for race T3 hypersensitivity in the greenhouse were clearly distinctive with Fla. 8517 exhibiting confluent necrosis in $24 \mathrm{~h}$ and Fla. 7946 showing a susceptible reaction in $72 \mathrm{~h}$ (Table 4). The $F_{1}$ between these parents had an intermediate reaction, averaging $33 \mathrm{~h}$ to confluent necrosis. Single marker analysis of the $\mathrm{F}_{2}$ progeny showed that hypersensitivity to race T3 was highly significantly associated with all markers tested on chromosome 11 (Table 5). Among these, the strongest association was with the more distal marker, cLEC-24-C3, and F values of nearby markers progressively decreased as markers were located more proximal to the centromere. The hypersensitivity phenotypes of $\mathrm{F}_{2}$ plants homozygous, heterozygous, or susceptible for the resistant allele at cLEC-24-C3 very closely resembled the Fla. 8517, $\mathrm{F}_{1}$, and Fla. 7946 phenotypes, respectively (Table 4). Field resistance to race $\mathrm{T} 4$ was also highly significantly associated with all markers tested on chromosome 11 (Table 5). In this case, as previously mentioned and conversely to race T3 hypersensitivity, field resistance to race $\mathrm{T} 4$ showed the strongest association with the marker C2_At4g10050, and F values of nearby markers progressively decreased as their distance from C2_At4g10050 increased. These results clearly suggest two separate loci involved in race $\mathrm{T} 3$ hypersensitivity and race $\mathrm{T} 4$ field resistance with the race T3 hypersensitivity locus located distal to the QTL.

\section{Discussion}

Bacterial spot is one of the most important diseases of tomato worldwide and is a major problem for the fresh-market industry in Florida. Conventional breeding for resistance has been ongoing at the University of Florida for more than three decades, yet these efforts have been unsuccessful at producing a resistant cultivar, and this timespan has only been punctuated by the development of tomato lines with race-specific resistance. Recent breeding efforts at the University of Florida have shifted toward identification of and selection for QTLs providing broad-spectrum resistance to multiple races. Hutton et al. (2010b) identified QTLs associated with non-hypersensitive 
Table 4. Hypersensitivity as measured by time to confluent necrosis in tomato plants infiltrated with Xanthomonas perforans race T3 in 2008.

\begin{tabular}{|c|c|c|c|c|c|c|c|c|}
\hline \multirow[b]{2}{*}{ Line } & \multirow{2}{*}{$\begin{array}{l}\text { Genotype at } \\
\text { cLEC-24-C } 3^{z}\end{array}$} & \multirow{2}{*}{$\begin{array}{c}\text { Total } \\
\text { plants (no.) }\end{array}$} & \multicolumn{5}{|c|}{ Frequency distribution of time to confluent necrosis ${ }^{y}$} & \multirow{2}{*}{$\begin{array}{c}\text { Avg time to } \\
\text { confluent necrosis }(\mathrm{h})\end{array}$} \\
\hline & & & $24 \mathrm{~h}$ & $36 \mathrm{~h}$ & $48 \mathrm{~h}$ & $60 \mathrm{~h}$ & $72 \mathrm{~h}$ & \\
\hline Fla. 8517 & $+/+$ & 16 & 16 & & & & & 24 \\
\hline (Fla. $8517 \times$ Fla. 7946$) \mathrm{F}_{1}$ & $+/-$ & 15 & 4 & 11 & & & & 33 \\
\hline \multirow[t]{2}{*}{ (Fla. $8517 \times$ Fla. 7946$) \mathrm{F}_{2}$} & $+/+$ & 60 & 54 & 5 & & & 1 & 26 \\
\hline & $+1-$ & 130 & 26 & 97 & 2 & 3 & 2 & 35 \\
\hline
\end{tabular}

${ }^{z_{+} /+}=$homozygous for $X$. perforans race T3 hypersensitivity resistance allele; $+/-=$ heterozygous; $-/-=$ homozygous-susceptible .

yPlants were infiltrated with $\approx 2$ to $5 \times 10^{8}$ colony-forming units $/ \mathrm{mL}$.

Table 5. Relationship between a quantitative trait loci conferring field resistance to Xanthomonas perforans race T4 and hypersensitivity to $X$. perforans race $\mathrm{T} 3$ on chromosome 11 in tomato.

\begin{tabular}{|c|c|c|c|c|c|}
\hline \multirow[b]{2}{*}{ Marker } & \multirow[b]{2}{*}{ Physical position $(\mathrm{Mbp})^{\mathrm{z}}$} & \multicolumn{2}{|c|}{ Race T4 field resistance } & \multicolumn{2}{|c|}{ Race T3 hypersensitivity } \\
\hline & & $\mathrm{F}$ & $P$ & $\mathrm{~F}$ & $P$ \\
\hline$\overline{C 2 \_A t 4 g 10050}$ & 31.8 & 95.43 & $<0.0001$ & 44.81 & $<0.0001$ \\
\hline LEOH 57 & 46.6 & 86.68 & $<0.0001$ & 49.48 & $<0.0001$ \\
\hline C2_At1g30825 & 50.3 & 40.37 & $<0.0001$ & 157.41 & $<0.0001$ \\
\hline C2_At3g54470 & 50.5 & 23.35 & $<0.0001$ & 143.18 & $<0.0001$ \\
\hline cLEC-24-C3 & 50.6 & 29.83 & $<0.0001$ & 409.76 & $<0.0001$ \\
\hline
\end{tabular}

${ }^{\mathrm{z}}$ Location based on version SL2.40 of the tomato genome assembly available through the Sol Genomics Network (Bombarely et al., 2011).

bacterial spot resistance on chromosomes 3,11 , and 12 as well as candidate loci on chromosomes $2,5,9$, and 10 .

The present study found no significant effect for the candidate loci on chromosomes 2, 9, or 10. QTLs on chromosomes 3,5 , and 12 were confirmed, but their effects were neither large nor consistent across all seasons or populations where they segregated. The QTL on chromosome 3 was significant in two populations segregating in 2008, but not in one segregating population in 2009. Its effect in 2008 was rather slight, lowering infection by only $2 \%$ to $5 \%$. The QTL on chromosome 12 was significant for one of two populations segregating in 2008 and also for one of two populations segregating in 2009, and it effected a reduction in infection of $4 \%$ to $8 \%$. The chromosome 5 QTL segregated in one population in 2008 and in one population in 2009. Its effect was significant only in 2008, where it accounted for a $3 \%$ reduction in infection. Whereas these loci may provide some use to breeders seeking to combine multiple QTLs, the relatively small and inconsistent effects present considerable difficulties in selection strategies. Part of this problem, however, could be a lack of tightly linked markers in the present study; thus, the development and use of improved markers may mitigate some of these difficulties.

The QTL on chromosome 11 consistently produced a strong effect, ranging from $14 \%$ to $25 \%$ reduction in infection, and this QTL may be of particular interest to breeders seeking to develop improved tolerance to bacterial spot race T4. Moreover, this QTL was found to confer broad-spectrum resistance (Francis et al., 2014; Hutton et al., 2010b) and should be useful across a range of production regions. Hutton et al. (2010a) determined that dominance was a major contributor to resistance in the breeding lines Fla. 8233, Fla. 8517, and Fla. 8326. The results of the present study are consistent with this, showing a dominant to incompletely dominant effect for this QTL. Use of this QTL heterozygously in a hybrid should contribute toward a reduction in bacterial spot disease, but incorporation of it into both parents of a hybrid should generally provide a higher level of tolerance.

The location of the chromosome 11 QTL near the centromere does not contradict previous results (Hutton et al., 2010b), and the location of the $X$. perforans race T3 hypersensitivity locus near the marker cLEC-24-C3 is in complete agreement with recent fine-mapping results (Pei et al., 2012). Recognizing that the two loci are distinct and that there is considerable recombination between them, it will be important to select both loci for environments where race T3 may be a problem. In such situations, it will likely be desirable to use the recombination of the QTL and race T3 hypersensitivity in cis. This could be accomplished independently, or breeders may wish to use materials such as Fla. 8233 in which the recombination has already been selected (Francis et al., 2014; Hutton et al., 2010b).

Tomato breeders who work with fusarium wilt race 3 resistance in regions where bacterial spot is prevalent have found that such materials tend to be extra susceptible to bacterial spot. This tendency was confirmed in the present study for every population that segregated for $I-3$. The three major fusarium wilt resistance alleles are regularly used by breeders in developing resistant cultivars, yet although most cultivars contain $I$ and $I-2$, not all current cultivars contain $I-3$. There may be several reasons for this. First, race 3 is not a problem in all production regions and thus resistance is not always needed. Along with this, because $I-3$ was more recently introgressed into cultivated tomato, it may be that more time is needed for $I-3$ to be incorporated into all modern cultivars. However, the findings of this study together with previous reports and observations indicate there are significant negative effects associated with $I-3$, including increased bacterial spot susceptibility, smaller vines, and smaller fruit size (Scott, 1999; Scott and Jones, 1995). It is thus likely that such negative effects significantly 
hamper the development of race 3 resistant cultivars, providing further explanation as to why $I-3$ is not more prevalent in current cultivars.

The association of I-3 with bacterial spot susceptibility has important implications for breeders seeking to develop cultivars for regions where both bacterial spot and fusarium wilt race 3 are problems. It is clear that breeding lines carrying $I-3$ will generally have greater susceptibility to bacterial spot than those without this resistance gene. In three of four populations evaluated across two seasons, plants heterozygous for $I-3$ had less disease than plants homozygous for the gene. On the positive side, because the $I-3$ gene is dominant, it is used heterozygously in commercial hybrids. Breeders should understand that homozygous $I-3$ plants in segregating populations will likely be more susceptible to bacterial spot as well as having smaller fruit size (Scott, 1999). Otherwise, there will be a tendency for continual selection of plants heterozygous for $I-3$.

It is not clear whether the association between $I-3$ and bacterial spot sensitivity is the result of linkage to unfavorable alleles or to pleiotropy. If the former, a directed effort to select for recombination near the $I-3$ gene may prove successful in breaking the linkage, and the fine mapping efforts of Lim et al. (2008) should prove helpful in this endeavor. If the problem is pleiotropy, however, strategies might involve efforts to accumulate multiple resistance QTL to offset the negative effect or to identify and incorporate alternative sources of fusarium wilt race 3 resistance that potentially do not have this association. Either approach is long term. Such prospects make alternative strategies such as the transgenic approach using the pepper $B s 2$ gene seem more attractive. Among the hybrids presented by Horvath et al. (2014) for which the $B s 2$ gene provided high levels of resistance was Fla. 8726, which contains $I-3$ and is otherwise highly sensitive to bacterial spot.

Ongoing research efforts at the University of Florida are seeking to address the $I-3$ association with bacterial spot through each of the conventional approaches mentioned. Materials with reduced $I-3$ introgressions are being developed and will soon be tested to determine if this relationship is the result of linkage and may be broken. Fusarium wilt race 3 resistance was found in all available accessions of $S$. pennellii (Scott and Jones, 1990). These accessions are being screened to determine if their resistance is allelic to $I-3$ or perhaps unique. Additionally, considerable effort is aimed at developing $I-3$ parents with a trait we call non-blighting, where plants maintain healthy, green foliage despite infection with bacterial spot. Several advanced breeding lines, including Fla. 630, carry this non-blighting trait, which is being advanced into an array of elite parent lines.

\section{Literature Cited}

Alexander, L.J. 1959. Progress report of national screening committee for disease resistance in tomato for 1954-1957. Plant Dis. Rptr. 43:55-65.

Bohn, G.W. and C.M. Tucker. 1939. Immunity to fusarium wilt in the tomato. Science 89:603-604.

Bombarely, A., N. Menda, I.Y. Tecl, R.M. Buels, S. Strickler, T. Fischer-York, A. Pujar, J. Leto, J. Gosselin, and L.A. Mueller. 2011. The Sol Genomics Network (solgenomics.net): Growing tomatoes using Perl. Nucleic Acids Res. D1149-D1155.

Byrne, J.M., A.C. Dianese, P. Ji, H.L. Campbell, D.A. Cuppels, F.J. Louws, S.A. Miller, J.B. Jones, and M. Wilson. 2005. Biological control of bacterial spot of tomato under field conditions at several locations in North America Biol. Control 32:408-418.
Food and Agriculture Organization of the United Nations. 2014. FAOSTAT statistical database. 10 Feb. 2014. <http://faostat. fao.org/>.

Francis, D., S.-C. Sim, S. Hutton, and J. Scott. 2014. OH 87663, OH 87667 , and $\mathrm{OH} 6117-\mathrm{S} 2$ processing tomato breeding lines and Fla. 8233 fresh market tomato breeding line with resistance to multiple species causing bacterial spot. HortScience (in press).

Fulton, T.M., J. Chunwongse, and S.D. Tanksley. 1995. Microprep protocol for extraction of DNA from tomato and other herbaceous plants. Plant Mol. Biol. Rpt. 13:207-209.

Hibberd, A.M., R.E. Stall, and M.J. Bassett. 1987. Different phenotypes associated with incompatible races and resistance genes in the bacterial spot disease of pepper. Plant Dis. 71:1075-1078.

Horsfall, J.G. and R.W. Barratt. 1945. An improved grading system for measuring plant diseases. Phytopathology 35:655.

Horvath, D.M., S.F. Hutton, G.E. Vallad, J.B. Jones, R.E. Stall, D. Dahlbeck, B.J. Staskawicz, D. Tricoli, A.V. Deynze, M.H. Pauly, and J.W. Scott. 2014. The pepper Bs2 gene confers effective field resistance to bacterial leaf spot and yield enhancement in Florida tomatoes. Acta Hort. (in press).

Horvath, D.M., R.E. Stall, J.B. Jones, M.H. Pauly, G.E. Vallad, D. Dahlbeck, B.J. Staskawicz, and J.W. Scott. 2012. Transgenic resistance confers effective field level control of bacterial spot disease in tomato. PLoS One 7:e42036.

Hutton, S.F., J.W. Scott, and J.B. Jones. 2010a. Inheritance of resistance to bacterial spot race $\mathrm{T} 4$ from three tomato breeding lines with differing resistance backgrounds. J. Amer. Soc. Hort. Sci. 135: $150-158$

Hutton, S.F., J.W. Scott, W. Yang, S. Sim, D.M. Francis, and J.B. Jones. 2010b. Identification of QTL associated with resistance to bacterial spot race T4 in tomato. Theor. Appl. Genet. 121:1275-1287.

Hutton, S.F., S.M. Smith, and J.W. Scott. 2012. Identification of molecular markers linked to bacterial spot race $\mathrm{T} 4$ resistance loci from the Solanum lycopersicum var. cerasiforme accession PI 114490: Toward developing a broad-spectrum resistance. HortScience 47:S186 (abstr.).

Jones, J.B., H. Bouzar, R.E. Stall, E.C. Almira, P.D. Roberts, B.W. Bowen, J. Sudberry, P.M. Strickler, and J. Chun. 2000. Systematic analysis of xanthomonads (Xanthomonas spp.) associated with pepper and tomato lesions. Intl. J. Syst. Evol. Microbiol. 50:1211-1219.

Jones, J.B., G.H. Lacy, H. Bouzar, G.V. Minsavage, R.E. Stall, and N.W. Schaad. 2005. Bacterial spot-worldwide distribution, importance and review. Acta Hort. 695:27-33.

Lim, G.T.T., G.P. Wang, M.N. Hemming, D.J. McGrath, and D.A. Jones. 2008. High resolution genetic and physical mapping of the $I-3$ region of tomato chromosome 7 reveals almost continuous microsynteny with grape chromosome 12 but interspersed microsynteny with duplication on Arabidopsis chromosomes 1,2 and 3. Theor. Appl. Genet. 118:57-75.

Louws, F.J., M. Wilson, H.L. Campbell, D.A. Cuppels, J.B. Jones, P.B. Showemaker, F. Sahin, and S.A. Miller. 2001. Field control of bacterial spot and bacterial speck of tomato using a plant activator. Plant Dis. 85:481-488.

Marco, G.M. and R.E. Stall. 1983. Control of bacterial spot of pepper initiated by strains of Xanthomonas campestris pv. vesicatoria that differ in sensitivity to copper. Plant Dis. 67:779-781.

McGrath, D.J., D. Gillespie, and L. Vawdrey. 1987. Inheritance of resistance to Fusarium oxysporum F. sp. lycopersici races 2 and 3 in Lycopersicon pennellii. Aust. J. Agr. Res. 38:729-733.

Obradovic, A., J.B. Jones, M.T. Momol, S.M. Olson, L.E. Jackson, B. Balogh, K. Guven, and F.B. Iriarte. 2005. Integration of biological control agents and systemic acquired resistance inducers against bacterial spot of tomato. Plant Dis. 89:712-716.

Olson, S.M., W.M. Stall, G.E. Vallad, S.E. Webb, S.A. Smith, E.H. Simonne, E. McAvoy, B.M. Santos, and M. Ozores-Hampton. 2011. Tomato production in Florida, p. 409-428. In: Olson, S.M. and B.M. Santos (eds.). Vegetable production handbook for Florida. Inst. Food Agr. Sci., Univ. Florida, Gainesville, FL. 
Pei, C., H. Wang, J. Zhang, Y. Wang, D.M. Francis, and W. Yang. 2012. Fine mapping and analysis of a candidate gene in tomato accession PI128216 conferring hypersensitive resistance to bacterial spot race T3. Theor. Appl. Genet. 124:533-542.

Pohronezny, K. and R.B. Volin. 1983. The effect of bacterial spot on yield and quality of fresh market tomatoes. HortScience 18:68-70.

Quezado-Duval, A.M., F.A. Gazzoto, J.R.P. Leite, and L.E.A. Camargo. 2003. Sensibilidade a cobre, estreptomicina e oxitetraciclina em Xanthomonas spp. associadas à mancha-bacteriana do tomate para processamento industrial. Horticultura Brasileira 21:670-676.

Robbins, M.D., A. Darrigues, S.-C. Sim, M.A. Taher Masud, D.M. Francis, and S.A. Miller. 2009. Characterization of hypersensitive resistance to bacterial spot race T3 (Xanthomonas perforans) from tomato accession PI 128216. Phythopathology 99:1037-1044.

Scott, J.W. 1999. Tomato plants heterozygous for fusarium wilt race 3 resistance develop larger fruit than homozygous resistant plants. Proc. Florida State Hort. Soc. 112:305-307.

Scott, J.W. 2004. Fla. 7946 tomato breeding line resistant to Fusarium oxysporum f.sp. lycopersici races 1, 2, and 3. HortScience 39:440441.

Scott, J.W., D.M. Francis, S.A. Miller, G.C. Somodi, and J.B. Jones. 2003. Tomato bacterial spot resistance derived from PI 114490; inheritance of resistance to race T2 and relationship across three pathogen races. J. Amer. Soc. Hort. Sci. 128:698-703.

Scott, J.W. and J.B. Jones. 1986. Sources of resistance to bacterial spot [Xanthomonas campestris pv. vesicatoria (Doidge) Dye] in tomato. HortScience 21:304-306.

Scott, J.W. and J.B. Jones. 1989a. Inheritance of resistance to foliar bacterial spot of tomato incited by Xanthomonas campestris pv. vesicatoria. J. Amer. Soc. Hort. Sci. 114:111-114.

Scott, J.W. and J.P. Jones. 1989b. Monogenic resistance in tomato to Fusarium oxysporum f.sp. lycopersici race 3. Euphytica 40:49-53.

Scott, J.W. and J.P. Jones. 1990. Soil-borne fungal resistance in Lycopersicon pennellii accessions. HortScience 25:1068 (abstr.).

Scott, J.W. and J.P. Jones. 1995. Fla. 7547 and Fla. 7481 tomato breeding lines resistant to Fusarium oxysporum f.sp. lycopersici races 1, 2, and 3. HortScience 30:645-646.
Scott, J.W., J.B. Jones, and G.C. Somodi. 2001. Inheritance of resistance in tomato to race T3 of the bacterial spot pathogen. J. Amer. Soc. Hort. Sci. 126:436-441.

Scott, J.W., R.E. Stall, J.B. Jones, and G.C. Somodi. 1996. A single gene controls the hypersensitive response of Hawaii 7981 to race 3 (T3) of the bacterial spot pathogen. Rpt. Tomato Genet. Coop. 46:23.

Sharlach, M., D. Dahlbeck, L. Liu, J. Chiu, J.M. Jimenez-Gomez, S. Kimura, D. Koenig, J.N. Maloof, N. Sinha, G.V. Minsavage, J.B. Jones, R.E. Stall, and B.J. Staskawicz. 2013. Fine genetic mapping of RXopJ4, a bacterial spot disease resistance locus from Solanum pennellii LA716. Theor. Appl. Genet. 126:601-609.

Simons, G., J. Groenendijk, J. Wijbrandi, M. Reijans, J. Groenen, P. Diergaarde, T. Van der Lee, M. Bleeker, J. Onstenk, M. de Both, M. Haring, J. Mes, B. Cornelissen, M. Zabeau, and P. Vos. 1998. Dissection of the fusarium $I 2$ gene cluster in tomato reveals six homologs and one active gene copy. Plant Cell 10:1055-1068.

Somodi, G.C., J.B. Jones, J.W. Scott, J.F. Wang, and R.E. Stall. 1996. Relationship between the hypersensitive reaction and field resistance to tomato race 1 of Xanthomonas campestris pv. vesicatoria. Plant Dis. 80:1151-1154.

Stall, R.E. and J.W. Walter. 1965. Selection and inheritance of resistance in tomato to isolates of races 1 and 2 of the fusarium wilt organism. Phytopathology 55:1213-1215.

U.S. Department of Agriculture. 2012. National Agricultural Statistics Service. 10 Feb. 2014. <http://www.nass.usda.gov>.

Wang, H., S.F. Hutton, M.D. Robbins, S.-C. Sim, J.W. Scott, W. Yang, J.B. Jones, and D.M. Francis. 2011. Molecular mapping of hypersensitive resistance from tomato 'Hawaii 7981 ' to Xanthomonas perforans race T3. Phytopathology 101:1217-1224.

Wang, J.F., J.B. Jones, J.W. Scott, and R.E. Stall. 1994. Several genes in Lycopersicon esculentum control hypersensitivity to Xanthomonas campestris pv. vesicatoria. Phytopathology 84:702-706.

Yang, W., E.J. Sacks, M.L. Lewis Ivey, S.A. Miller, and D.M. Francis. 2005. Resistance in Lycopersicon esculentum intraspecific crosses to race T1 strains of Xanthomonas campestris pv. vesicatoria causing bacterial spot of tomato. Phytopathology 95:519-528. 